\title{
A Novel Single Nucleotide Polymorphism in Exon 4 of Insulin-Like Growth Factor-1 Associated with Production Traits in Bali Cattle
}

\author{
Maskur $^{a, *}$, C. Arman ${ }^{a}$, C. Sumantri ${ }^{b}$, E. Gurnadi ${ }^{b}, \&$ Muladno $^{\text {b }}$ \\ aFaculty of Animal Science, Mataram University \\ Kampus Gomong, Jln. Majapahit, Mataram-Nusa Tenggara Barat, Indonesia \\ bDepartment of Animal Production and Technology, Faculty of Animal Science, Bogor Agricultural Unversity \\ Jln. Agatis, Kampus IPB Darmaga Bogor 16680, Indonesia \\ (Received 30-11-2011; accepted 20-02-2012)
}

\begin{abstract}
ABSTRAK
Insulin-like growth factor-1 (IGF-1) adalah salah satu kandidat gen dalam strategi seleksi menggunakan marka DNA (marker assisted selection). Strategi kandidat gen merupakan teknik biologi molekuler untuk mengidentifikasi lokus sifat kuantitatif secara langsung, dengan asumsi bahwa variasi genetik kandidat gen ini berasosiasi dengan sifat kuantitatif. Penelitian ini dirancang untuk mengidentifikasi adanya mutasi baru pada exon 4 yang dapat menimbulkan polimorfisme gen IGF-1 yang mempengaruhi sifat produksi pada sapi bali. Pencarian single nucleotide polymorphism (SNPs discovery) dilakukan menggunakan metode "direct sequencing", sedangkan variasi genetik kandidat gen ini diidentifikasi menggunakan teknik "polymerase chain reaction-restriction fragment length polymorphism" (PCR-RFLP). Hasil penelitian ini menunjukkan bahwa pada exon 4 gen IGF-1 ditemukan SNPS baru, yaitu mutasi transisi T/C, yang kemudian dapat identifikasi menggunakan enzim restriksi Rsa1. Polimorfisme genotipe IGF-1/Rsa1 memiliki pengaruh yang signifikan terhadap bobot lahir, bobot sapih, dan rata-rata pertambahan bobot badan harian sapi bali. Genotipe CC memiliki angka bobot lahir, bobot sapih, dan rata-rata pertambahan bobot badan harian berturut-turut:

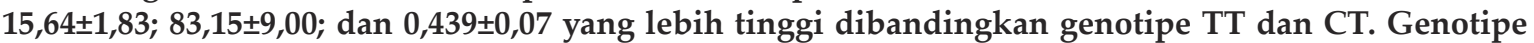
IGF-1/ Rsa1 dapat digunakan sebagai penciri genetik untuk seleksi bobot lahir, bobot sapih, dan pertambahan bobot badan harian.
\end{abstract}

Kata kunci: gen, mutasi, restriksi, polimorfisme, marka, seleksi

\begin{abstract}
Insulin-like growth factor-1 (IGF-1) is one of the gene candidates that can be used in selection strategy by using DNA markers (marker assisted selection). Gene candidate strategy is a molecular biology techniques to identify quantitative trait loci directly, with the assumption that genetic variation associated to quantitative trait variation. This study was designed to identify any new mutations in exon 4 that can cause the IGF-1 gene polymorphism and then affect the production traits on Bali cattle. Single nucleotide polymorphism (SNP) discovery was conducted by using the direct sequencing technique. Genetic variation of the genes candidate was identified by using PCR-RFLP technique. The results of this study indicate the presence of a new SNP in exon 4 of IGF-1 gene caused by the T/C transition, which can be identified using Rsa1 restriction enzyme. Genotypic polymorphism of IGF-1/Rsa1 has a significant influence on birth weight, weaning weight and average daily gain of Bali cattle. CC genotype had a birth weight rate, weaning weight and average daily gain of: 15.64 \pm 1.83 ; $83.15 \pm 9.00$, and $0.439 \pm 0.07$ respectively, higher than the TT and CT genotype. IGF-1/Rsa1 can be used as a genetic marker for selection of birth weight, weaning weight, and daily body weight gain.
\end{abstract}

Key words: gene, transition, restriction, polymorphism, markers, selection

\footnotetext{
* Corresponding author:

E-mail: maskur07@yahoo.co.id
} 


\section{INTRODUCTION}

Insulin-like growth factor-1 (IGF-1) is a polypeptide with a molecular weight of $7.5 \mathrm{kDa}$ and consists of 70 amino acids (Daughaday \& Rotwein, 1989). Amino acid sequences of IGF-1 is identical in humans, cows, dogs, and pigs with the IGF-1 nucleotide sequence is about 70-90 kb (Shimatsu \& Rotwein, 1987; Rose, 2002). In cattle, IGF-1 gene is located on chromosome 5 (Miller et al., 1991). The number of exon is different between species, for example: goat, pigs, and sheep have 1-5 exon (Mikawa et al., 1995), human and rats have 1-5 (Shimatsu \& Rotwein, 1987), while bovine IGF-1 has 6 exons which is responsible for expressing heterogeneous mRNA (Wang et al., 2003).

IGF-1 gene formed two alternative transcripts caused by the presence of "splicing" of exon 1 and 2, namely: transcripts with exon 1 contains 1155 nucleotides and the exon 2 containing 750 nucleotides. Production of both transcripts are controlled by two different promoters, each of which contain sequenceregulator-TATA-box and CCAAT-box. Transcripts of the two classes differently expressed in various tissues, and most of them in the liver. In all tissues tested in cattle, expression of IGF-1 class 1 is higher than transcript 2. This suggests that the expression of IGF-1 is arranged in two levels of transcription and translation (Wang et al., 2003).

The results of the study on some breeds cows showed that levels of IGF-1 in the blood are associated with cell proliferation and growth. Levels of IGF-1 in the blood were significantly higher in Simmental cattle than that of Holstein cows, and the differences in these levels are associated with growth rate (Sirotkin et al., 2000). Barash et al. (1998) also reported that there are relationship between IGF-1 levels in the blood and the rate of growth in cattle. In contrast, Ge et al. (2001) suggested that the correlation between IGF-1 levels in the blood and body weight was negative in Angus cattle.

The polymorphisms of nucleotide sequence of IGF1 gene in cattle and its relationship with growth rate have been widely reported. Kirkpatrick (1992) reported the polymorphisms of microsatellite at 5'non coding region and SSCP in intron 3. Moody et al. (1996) showed that the polymorphisms of microsatellite are associated with birth weight, weaning weight and growth rate in Hereford cattle. SSCP is also found in the 5'non coding region of IGF-1 gene by Ge et al. (1997) in Angus cattle. The polymorphisms were identified as RFLP-SnaB1, located at regulatory sequences $512 \mathrm{bp}$ from the start codon (initiation codon) and known to be caused by mutations of the T/C transition (Ge et al., 2001). Li et al. (2004) found two alleles and three genotypes at position 472 regulatory sequences. Frequency of A allele (nt T) was found to be higher than frequency of allele B (nt C) for IGF-1 content in the blood. Curi et al. (2005) studied with some Nellore, Canchim and several population crosses of cattle is founded a significant association of SNP with body weight and subcutaneous backfat. Due to its biological function, the IGF1 gene is considered to be a candidate gene for predicting growth traits in animal genetic improvement schemes (Machado et al., 2003; Andrade et al., 2008).

The aim of the study was to determine the effect of the IGF-1 gene polymorphism on production traits in Balinesse cattle. In addition, we made a search for new SNP in coding regions (exon 4) of the IGF-1 gene.

\section{MATERIALS AND METHODS}

\section{Phenotyping}

Two hundred and fifty Bali cattle of 6-7 mo old were used in this study. All animals were reared under intensive conditions. Thie samples were composed of 134 males and 116 females. All cattles were raised in groups or collective barns. Their feed mainly consisted of native grass, introduced grass and rice brand, and mineral supplement.

The avarage of daily gain was measured weekly by weighing the cattle for 3 mo period. Secondary data on calves birth weight and weaning weight at 6 mo old as previously recorded by ACIAR adn JICA was also used to complement the quantitative data.

\section{SNP Discovery}

DNA genome extraction of two hundred and fifty Bali cattle was carried out using procedures described by Sambrook et al. (1989). Amplification was carried out following the method previously used by Reyna et al. (2010). The PCR reaction volume $25 \mu \mathrm{l}$ consisted of $100 \mathrm{ng}$ DNA, $0.5 \mu \mathrm{M}$ of each primer, $1 \times$ PCR buffer $(10$ $\mathrm{mM}$ Tris- $\mathrm{HCl} \mathrm{pH} 9.0), 1.5 \mathrm{mM} \mathrm{MgCl}$ and $50 \mathrm{mM} \mathrm{KCl}$, $5 \%$ deionized Formamide, $200 \mu \mathrm{M}$ dNTPs, and $0.25 \mathrm{U}$ Taq DNA polymerase (Pharmacia). Amplification was performed for 35 cycles in which the first cycle was at 94 ${ }^{\circ} \mathrm{C}$ for $5 \mathrm{~min}$ followed by 33 subsequent cycles of $94{ }^{\circ} \mathrm{C}$ x $30 \mathrm{sec}$ each, $60{ }^{\circ} \mathrm{C}$ x $45 \mathrm{sec}$, and $72{ }^{\circ} \mathrm{C}$ x $90 \mathrm{sec}$ and the last cycle at $72{ }^{\circ} \mathrm{C}$ for $5 \mathrm{~min}$, using DNA thermal Cycler (Perkin Elmer Cetus Corp.). Sequence and position of the primer is presented in Table 1.

SNPs identification in the gene fragments were conducted by the "direct sequencing method". Firstly, DNA samples (PCR products) were grouped in the form of "DNA Pool" based on the group of farmers in each district. Sequencing of DNA fragment was carried out by AB3730xl sequencer machine. Sequence alignment was performed using the BioEdit and Mega4 program. The alignment of sequences "reverse and forward"

Table 1. Sequence and position of the primer

\begin{tabular}{|c|c|c|c|}
\hline Gene & Sequence & \multicolumn{2}{|c|}{ Location and position } \\
\hline IGF-I & $\begin{array}{l}\text { F: 5'-CCACTCTAAAGCTAGGCCTCTCTC-3' } \\
\text { R: 5'-GAAGTCTATGAGGGTATGAAT-3' }\end{array}$ & Exon 4 & $56127-56470 \mathrm{bp}$ \\
\hline
\end{tabular}


were applied to produce consensus sequences. These sequences of each individual were aligned with IGF-1 sequences from gene bank (acc. no. AF210386) to identify the presence of SNPs.

\section{Genotyping of Gene Candidate}

Determination of genotypes of each cattle was conducted based on the SNPs that were found on the SNPs discovery stage. Genotyping was performed by amplification of gene fragments containing the SNPs using a PCR machine, there after the gene fragments were cut using a specific restriction enzyme. The size and number of alleles were determined by using agarose gel electrophoresis. T allele was the SNP allele with fragment size of 203-bp and $142 \mathrm{bp}$ (uncut allele by Rsa1), whereas the C allele was SNP with fragment size of 203, 87, and 55 bp (cut allele by Rsa1).

\section{Statistical Analysis}

Genotype and allele frequencies for each polymorphism and the differences in the allele frequencies of the polymorphisms within and between genetic groups were determined by the method of Goodman adapted by Curi et al. (2005). For the association studies, the traits of interest were analyzed using the general linear model (GLM) procedure and the least square means of the genotypes were compared by the T-test. The linear model used as follows:

$$
Y i j=\mu+G i+e i j
$$

where Yijk= production trait, $\mu=$ overall mean, $\mathrm{Gi}=$ fixed effect of the IGF-1 genotype, and eij=random error.

\section{RESULTS AND DISCUSSION}

\section{SNP Discovery in Exon 4 of IGF-1 Gene}

The results of sequence alignment showed that there were new mutation in exon 4 of IGF-1 gene (Figure $1)$. Mutations in this locus are the transition mutation that changes Thymine bases into Cytosin at position $17 \mathrm{bp}$. Transition mutation is a mutation of thymine to cytosine base substitution or otherwise, cytosine bases with thymine. The point mutations changed the amino acid sequence of IGF-1 in which methionine (AUG) changed to threonine (ACG). These mutations can be identified using restriction enzyme Rsa1 (Figure 2). The digestion using Rsa1 produces two alleles, namely $\mathrm{T}$ and $\mathrm{C}$ alleles. $\mathrm{T}$ allele which is not being cut by Rsa1, produced two DNA fragments: 203-bp and 142 bp, while $C$ allele which is being cut by $R s a 1$, produced three DNA fragments: 203, 87, and $55 \mathrm{bp}$. The digestion of the IGF-1 locus occurred because of mutations that cause Rsa1 enzyme recognized the sequence (GT $\downarrow$ AC) as the site of cutting.

The IGF-1 SNP has been studied in various cattle breeds, including dairy and beef breeds. Reyna et al. (2010) found five new SNPs in the IGF-1 gene from the Charolais and Beefmaster breeds: two transitions in 5'UTR, one indel in intron 2, one transition and one transversion in intron 4. Mullen et al. (2011) reported 9 new SNP in 5'promotor region, intron and 3'regulatory region of IGF-1 gene from beef and dairy cattle. Some of the SNPs was reported in association with beef and dairy production traits.

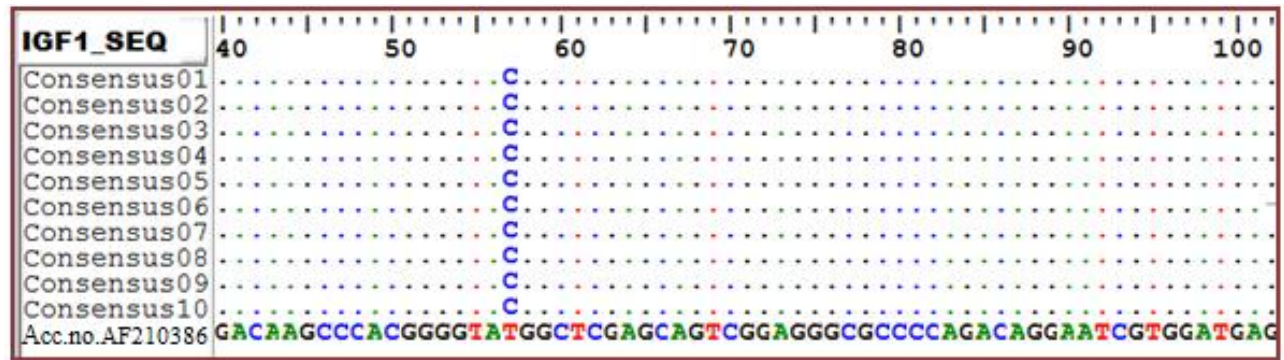

Figure 1. Sequence alignment exon 4 of IGF-1 gene

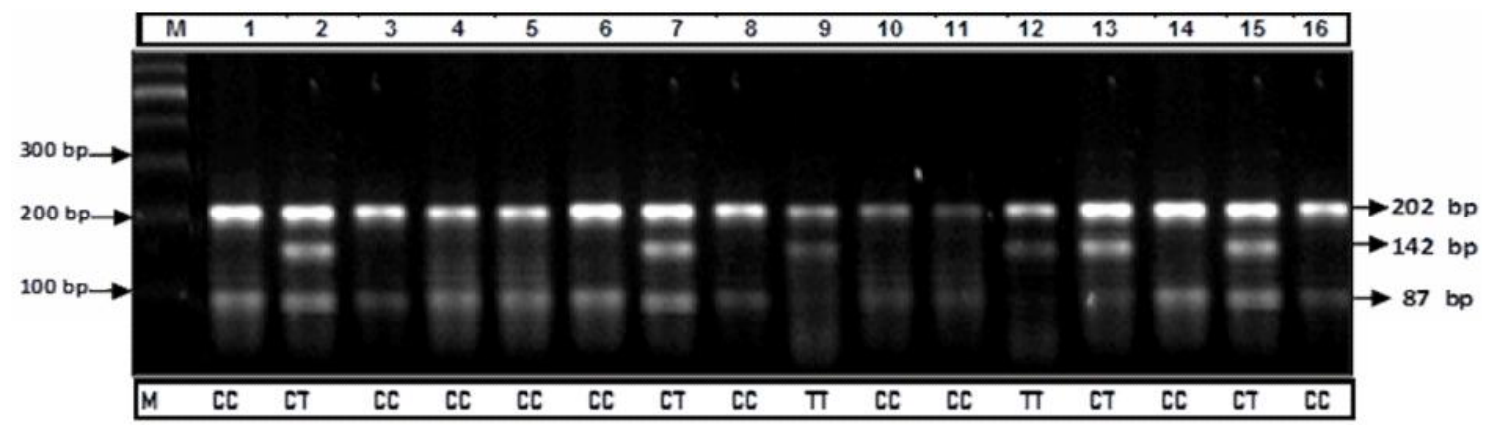

Figure 2. Allelic polymorphism of IGF-1/Rsa1 locii 


\section{Allelic and Genotypic Frequencies of the IGF-1/Rsa1 Gene in Balinesse cattle}

There are contrasting allelic frequencies distributions between $\mathrm{T}$ and $\mathrm{C}$ allele in IGF-1 gene of Balinesse cattle. The frequency of $\mathrm{C}$ allele was higher than the frequency of $\mathrm{T}$ allele, the frequencies were 0.836 and 0.164 respectively (Table 2). Reyna et al. (2010) reported that the T/C transition in intron 4 produced $\mathrm{T}$ and $\mathrm{C}$ allele with the contrasting allelic frequencies. The allelic frequencies distribution of $\mathrm{C}$ allele was relatively higher than the T allele, i.e. 0.70 and 0.30 in Beefmaster cattle and 0.52 and 0.48 in Charolais cattle. T/C transition in the promoter region (SNP IGF-1/SnaB1) was equal to the $\mathrm{T} / \mathrm{C}$ transition in intron 4 in which the frequency of $\mathrm{C}$ allele was higher than $\mathrm{T}$ allele. The frequency of $\mathrm{C}$ allele was 0.97 in Beefmaster cattle and 0.74 in Charolais cattle. According to Curi et al. (2005), the C allele is a characteristic of Bos indicus cattle because of the existence of a highly conservative $C$ allele in Nellore cattle population.

Using RFLP-RsaI, 250 Balinesse cattle were genotyped at T/C polymorphism. The following genotype frequency was estimated: TT-0.136, CT-0.080, and $\mathrm{CC}-0.784$. The $\mathrm{X}^{2}$ test showed that the genotype distributions of exon 4 IGF-1 gene were in disagreement with Hardy-Weinberg equilibrium in balinesse cattle. The genotype frequencies at polymorphic loci of exon 4 IGF1 gene showed a highly significant difference $(P<0.01)$.

Data in Table 3 show the results of genetic index measurements in Bali cattle population. Expectations of heterozygosity values has an important meaning to describe the description about the genetic variability (Marson et al., 2005). Based on this data, the observation value of heterozygosity was 0.080 lower than the expectation value of heterozygosity. This was an indicator of genotypic imbalance in the population where genotype heterozygote frequencies was lower than HardyWeinberg expectation agreement. This was due to inten- sive selection (Tambasco et al., 2003) and the possibility of marriage within the group as endogamy (Machado et al., 2003). In this study, the genotype imbalance was caused by the tendency of genotype accumulation as a result of intensive selection process. This might also be explained because the present was conducted on groups of intensive commercial farms.

Ne values (1.408) illustrates that the IGF-1 gene alleles in the population have very different frequencies in which one allele is dominant allele frequencie. Based on the classification of the PIC (PIC $\leq 0.25$ low polymorphism, $0.25 \leq \mathrm{PIC} \leq 0.5$ medium polymorphism, and $\mathrm{PIC} \geq 0.5$ high polymorphism), IGF-1 gene polymorphism in Balinesse cattle population is at the medium level. PIC value of 0.25 , indicated that the genetic diversity within populations was not very high. Zulkharnaim et al. (2010) also reported that Bali cattle had a low genetic diversity at GHR/Alu1 loci in exon 10 of GHR gene.

\section{Association of IGF-1 Gene Polymorphism with Production Traits}

The results of association analysis between the IGF-1 gene genotype and birth weight, weaning weight and avarage daily gain in Balinesse cattle is presented in Table 4 . The genotype of IGF-1 gene affected $(\mathrm{P}<0.01)$ birth weight, weaning weight and average daily gain in Balinesse cattle.

CC genotype had a significant effect $(\mathrm{P}<0.01)$ on birth weight, weaning weight and average daily gain compared with the CT and TT genotypes. No significant differences in birth weight and weaning weight were observed in the CT and TT genotypes, however the average daily gain was differed significantly $(\mathrm{P}<0.05)$. $\mathrm{C}$ allele gave a dominant effect on birth weight, weaning weight and average daily gain in Balinesse cattle. Ge et al. (2001) reported that the BB genotype (nucleotide C) and $A B$ genotype had a higher weaning weight and

Table 2. Allelic and genotypic frequencies of the IGF-1/Rsa1 gene in Balinesse cattle

\begin{tabular}{|c|c|c|c|c|c|c|c|}
\hline \multirow{2}{*}{ Gene } & \multirow{2}{*}{$\mathrm{N}$} & \multicolumn{2}{|c|}{ Allelic frequencies } & \multicolumn{3}{|c|}{$\begin{array}{l}\text { Genotypic observation and genotypic } \\
\text { frequencies }\end{array}$} & \multirow{2}{*}{$\mathrm{X}^{2}(\mathrm{HWE})$} \\
\hline & & $\mathrm{C}$ & $\mathrm{T}$ & $\mathrm{CC}$ & $\mathrm{CT}$ & $\mathrm{TT}$ & \\
\hline IGF-1 & 250 & 0.824 & 0.176 & $196 / 0.784$ & $20 / 0.080$ & $34 / 0.136$ & $131.11^{* *}$ \\
\hline
\end{tabular}

Note: Superscript ${ }^{* *}=\mathrm{P}<0.01 ; \mathrm{HWE}=$ Hardy-Weinberg Equilibrium.

Table 3. Genetic indexes measurement in Bali cattle population

\begin{tabular}{cccccc}
\hline GENE & Ho & He & se & Ne & PIC \\
\hline IGF-1 & 0.080 & 0.290 & 0.0249 & 1.408 & 0.25 \\
\hline
\end{tabular}

Note: $\mathrm{Ho}=$ observation of heterozygosity; $\mathrm{He}=$ expectations of heterozygosity; $\mathrm{Ne}=$ effective allele number; $\mathrm{PIC}=$ polymorphic information contents; se= standard error.
Table 4 . Birth weight, weaning weight and avarage daily gain in balinesse cattle base on genotype of IGF-1 gene

\begin{tabular}{ccccc}
\hline & & \multicolumn{3}{c}{ Avarage } \\
\cline { 3 - 5 } Genotipe & $\mathrm{N}$ & $\begin{array}{c}\text { Birth weight } \\
(\mathrm{kg})\end{array}$ & $\begin{array}{c}\text { Weaning } \\
\text { weight }(\mathrm{kg})\end{array}$ & $\begin{array}{c}\text { Avarage daily } \\
\text { gain }(\mathrm{kg} / \text { day })\end{array}$ \\
\hline $\mathrm{CC}$ & 148 & $15.64 \pm 1.83^{\mathrm{a}}$ & $83.15 \pm 9.00^{\mathrm{a}}$ & $0.439 \pm 0.07^{\mathrm{a}}$ \\
$\mathrm{CT}$ & 15 & $14.23 \pm 1.03^{\mathrm{b}}$ & $77.47 \pm 11.37^{\mathrm{b}}$ & $0.356 \pm 0.05^{\mathrm{b}}$ \\
TT & 21 & $14.00 \pm 1.84^{\mathrm{b}}$ & $75.81 \pm 6.35^{\mathrm{b}}$ & $0.323 \pm 0.02^{\mathrm{c}}$ \\
\hline
\end{tabular}

Note: Means in the same column with different superscript differ significantly at $(\mathrm{P}<0.05)$ and $(\mathrm{P}<0.01)$. 
lower serum IGF-1 concentration in the blood $(\mathrm{P}<0.05)$ than AA genotype (T nucleotides) as well. The $\mathrm{B}$ allele (nucleotide $\mathrm{C}$ ) had more dominant effect than the A allele (T nucleotides) $(\mathrm{P}<0.01)$ as previously reported in Angus cattle (Ge et al., 2001; Islam et al. 2009), Nellore cows, Canchim, Simmental $x$ Angus and Angus $x$ Nellore (Curi et al., 2005), Holstein Friesian (Siadkowska et al., 2006), and the Mexican Charolais cattle (Reyna et al., 2010).

A polymorphism in exon 4 of IGF-1 gene associated directly with birth weight, weaning weight and avarage daily gain in Bali cattle. IGF-1 plays an important role on the growth of many tissues and has been shown to activate mitogenic proliferation and myogenic differentiation in skeletal muscle (Lee, 2003). IGF-1 stimulate both satellite cell proliferation and fusion in primary satellite cell culture and to increase myonucleus number and myofiber size in tissue. Therefore, IGF-1 mediates the hypertrophy response via activation of satellites cells. IGF-1 is also crucial for mammary gland growth and function by regulating several cellular processes (Akers, 2006).

The action of IGF-1 are regulated by IGF-1 receptor and IGFBPs. IGF-1 binds to receptor located in the cell membrane and sends a signal to various cytoplasmic substrates. IGF-1 receptor interacts with intermediate signaling protein, insulin receptor substrate and Src homology containing protein (Shc), changes transcription and translation via mitogen activate protein kinase. IGF-1 also binds to varous binding proteins (IGFBP) to extend its half-life and modulate its binding affinity and transport across vascular barriers (Lee, 2003).

The results on goats, the $\mathrm{T} / \mathrm{C}$ transition located in exon 4 IGF-1 gene. This SNP significanly affected goat production traits. At the exon 4 IGF-1 gene, there were two novel mutations detected in the three breed of indigenous goat: China Xinjiang local goat, cashmere and Nanjiang Bogeda Cashmere. These mutations were the transition of $\mathrm{T} / \mathrm{C}$ and $\mathrm{A} / \mathrm{G}$. These mutation caused the polymorphism of IGF-1 gene and showed a significant association with goat production traits (Qiong et al., 2011; Jun et al., 2010).

IGF-1 gene SNPs in the promoter region, UTR, exon and intron have been reported in various breed of cattle, including dairy and beef cattle. In the promoter region, there were two polymorphism, i.e. microsatellite CAn (Kirkpatrick, 1992) and the T/C transition, known as SNPs IGF-1/SnaB1 (Ge et al., 2001). In exon 1, the T/C transition in IGF-I gene showed a significant association $(\mathrm{P}<0.05)$ with weight at 3 mo old $(\mathrm{W} 3)$, and $\mathrm{AB}$ genotype had higher W3 than BB genotype in Korean cattle (Hanwoo) (Chung \& Kim, 2005). Reyna et al. (2010) found five mutations that located in the IGF-1 gene from the Charolais and Beefmaster breeds: two transitions in $5^{\prime}$ UTR, one indel in intron 2 , one transition and one transversion in intron 4.

\section{CONCLUSION}

The $\mathrm{T} / \mathrm{C}$ transition resulted in three genotypes SNP (TT, CT, and CC) and two alleles (T and C). Polymorphism of IGF-1/Rsa1 genotype had a significant effect on birth weight, weaning weight, and average daily gain for Balinesse cattle. CC genotype had a birth weight rate, weaning weight, and average daily gain that were higher than in the TT and CT genotype. IGF-1/Rsa1 can be used as a genetic marker for selection of birth weight, weaning weight, and daily body weight gain.

\section{ACKNOWLEDGEMENT}

This research was founded by the Directorat General of Higher Education, Departement of National Education, The Republic of Indonesia. We thanks Dr. Dahlanuddin (Faculty of Animal Science, University of Mataram, West Nusa Tenggara Province, Indonesia) for Data support in Bali cattle.

\section{REFERENCES}

Akers, R. M. 2006. Major advances associated with hormone and growth factor regulation of mammary growth and lactation in dairy cows. J. Dairy Sci. 89: 1222-1234. http:// dx.doi.org/10.3168/jds.S0022-0302(06)72191-9

Andrade, P. C., D. A. Grossi, C. C. Paz, \& M. M. Alencar. 2008. Association of an insulin-like growth factor 1 gene microsatellite with phenotypic variation and estimated breeding values of growth traits in Canchim cattle. Anim. Genet. 39: 480-485. http://dx.doi.org/10.1111/j.1365-2052.2008.01755.x

Barash, H., Y. Aharoni, A. Brosh, \& Z. Holzer. 1998. Effect of low energy diets followed by a compensatory diet on body weight gain and plasma hormone concentrations in bull calves. J. Dairy Sci. 81, 250-254. http://dx.doi.org/10.3168/ jds.S0022-0302(98)75573-0

Chung, E. R. \& W. T. Kim. 2005. Association of SNP Marker in IGF-I and MYF5 Candidate Genes with Growth Traits in Korean Cattle. Asian-Aust. J. Anim. Sci. 18: 1061-1065.

Curi, R. A., H. N. de Oliveira, A. C. Silveira, \& C. R. Lopes. 2005. Association between IGF-I, IGF-IR and GHRH gene polymorphisms and growth and carcass traits in beef cattle. Livest. Sci. 94: 159-167. http://dx.doi.org/10.1016/ j.livprodsci.2004.10.009

Daughaday, W. H. \& P. Rotwein. 1989. Insulin-like growth factors I and II:Peptide messenger ribonucleic acid and gene structures, serum, and tissue concentrations. Endocrin. Rev. 10: 68-91. http://dx.doi.org/10.1210/edrv-10-1-68

Ge, W., M. E. Davis, \& H. C. Hines. 1997. Two SSCP alleles detected in the $5^{\prime}$-flanking region of bovine IGF-1 gene. Anim. Genet. 28: 155-156.

Ge, W., M. E. Davis, H. C. Hines, \& K. M. Irvin. 2001. Association of a genetic marker with blood serum insulin-like growth factor-I concentration and growth traits in Angus cattle. J. Anim. Sci. 79: 1757-1762.

Islam, K. K., M. Vinsky, R. E. Crews, \& E. Okine. 2009. Association analyses of a SNP in the promoter of IGF1 with fat deposition and carcass merit traits in hybrid, Angus and Charolais beef cattle. Anim. Genet. 40: 766-769. http:// dx.doi.org/10.1111/j.1365-2052.2009.01912.x

Jun, L. W., F. G. Xin, F. Yi, T. K. Chuan, H. X. Xia, Y. X. Kui, W. Mou, Y. Hui, H. Y. Zhen, X. J. Jing, X. Y. Ping, Y. S. Gang, \& C. Hong. 2010. The polymorphism of a mutation of IGF1 gene on two goat breeds in China. J. Anim. Vet. Adv. 9: 790-794. http://dx.doi.org/10.3923/javaa.2010.790.794

Kirkpatrick, B. W. 1992. Identification of a conserved microsatellite site in the porcine and bovine insulin-like growth factor-I gene 5' flank. Anim. Genet. 23: 543-548. http://dx.doi. org/10.1111/j.1365-2052.1992.tb00176.x

Lee, S. 2003. Insulin-like growth factor-I induces skeletal muscle hypertropy. Journal of Excercise Sciences and Fitnes. 1: 47- 
53

Li, C., J. Basarab, W. M. Snelling, \& B. Benkel. 2004. Assessment of positional candidate genes myf5 and IGF-1 for growth on bovine chromosome 5 in commercial lines of Bos taurus. J. Anim. Sci. 82: 1-7.

Machado, M. B. B., M. M. Alencar, A. P. Pereira, \& H. N. Oliveira. 2003. QTL affecting body weight in a candidate region of cattle chromosome 5. Genet. Mol. Biol. 26: 259265. http://dx.doi.org/10.1590/S1415-47572003000300008

Marson, E. P., J. B. S. Ferraz, F. V. Meirelles, J. C. de Carvalho Balieiro, J. P. Eler, L. G. G. Figueiredo, \& G. B. Mourão. 2005. Genetic characterization of European-Zebu composite bovine using RFLP markers. Genet. Mol. Res. 4: 496505.

Mikawa S., G. Yoshikawa, H. Aoki, \& Y. Yamano. 1995. Dynamic aspects in the expression of the goat insulin-like growth factor-I (IGF-I) gene: diversity in transcription and post-transcription. Biosci. Biotechnol. Biochem. 59: 87-92. http://dx.doi.org/10.1271/bbb.59.87

Miller, J. R., P. D. Thomsen, S. C. Dixon, E. M. Tucker, B. A. Konfortov, \& I. Harbitz. 1991. Synteny mapping of the bovine IGHG2, CRC and IGF-1 genes. Anim. Genet.s 23, 51-58.

Moody, D. E., D. Pomp, S. Newman, \& M. D. MacNeil. 1996. Characterization of DNA polymorphisms in three populations of Hereford cattle and their associations with growth and maternal EPD in line 1 Herefords. J. Anim. Sci. 74:1784-1793.

Mullen, M. P., C. O. Lynch, S. M. Waters, D. J. Howard, P. O'Boyle, D. A. Kenny, F. Buckley, B. Horan, \& M. G. Diskin. 2011. Single nucleotide polymorphisms in the growth hormone and insulin-like growth factor-1 genes are associated with milk production, body condition score and fertility traits in dairy cows. Genet. Mol. Res. 10: 1819-1830. http://dx.doi.org/10.4238/vol10-3gmr1173

Qiong, W., F. Chao, L. W. Jun, F. Yi, \& Y. S. Gang. 2011. A novel mutation at exon 4 of IGF-1 gene in three indigenous goat breeds in China. Asian J. Anim. Vet. Adv. 6: 627-635. http:// dx.doi.org/10.3923/ajava.2011.627.635
Reyna, X. F. De la Rosa, H. M. Montoya, V. V. Castrellón, A. M. S. Rincón, M. P. Bracamonte, \& W.A. Vera, 2010. Polymorphisms in the IGF-1 gene and their effect on growth traits in Mexican beef cattle. Genet. Mol. Res. 9: 875-883. http://dx.doi.org/10.4238/vol9-2gmr745

Rose, M. T. 2002. The somatotropic axis of the dairy cow revisited. Anim. Sci. J. 73: 13-19. http://dx.doi.org/10.1046/ j.1344-3941.2002.00002.x

Sambrook, J., E. F. Fritsch, \& T. Maniatis. 1989. Molecular Cloning: A laboratory Manual. 2nd ed. Cold Spring Harbor Laboratory Press, USA.

Shimatsu, A. \& P. Rotwein. 1987. Mosaic evolution of the insulin-like growth factors. Organization, sequence, and expression of the rat insulin-like growth factor I gene. J. Biol. Chem. 262: 7894-7900.

Siadkowska, E., L. Zwierzchowski, J. Oprzdek, N. Strzałkowska, E. Bagnicka, \& J. Krzyewski. 2006. Effect of polymorphism in IGF-1 gene on production traits in Polish Holstein-Friesian cattle. Anim. Sci. Pap. Rep. 24: 225-237.

Sirotkin, A. V., P. Chrenek, A. V. Makarevich, J. Huba, \& J. Bulla. 2000. Interrelationships between breed, growth hormone, plasma IGF-I level and meat performance in bulls of different ages. Archiv fuer Tierzucht 6: 591-596.

Tambasco, D. D., C. C. P. Paz, M. Tambasco-Studart, A. P. Pereira, M. M. Alencar, A. R. Freitas, L. L. Coutinho, I. U. Packer, \& L. C. A. Regitano. 2003. Candidate genes for growth traits in beef cattle crosses Bos taurus X Bos indicus. J. Anim. Breed. Genet. 120:51-54. http://dx.doi.org/10.1046/ j.1439-0388.2003.00371.x

Wang, Y., S. E. Price, \& H. Jiang. 2003. Cloning and characterization of the bovine class 1 and class 2 insulin-like growth factor-I mRNAs. Domest. Anim. Endocrinol. 25: 315-328. http://dx.doi.org/10.1016/j.domaniend.2003.06.001

Zulkarnaim, Jakaria, \& R. R. Noor. 2010. Identification of genetic diversity of Growth Hormone Receptor (GHR/Alu1) gene in Bali cattle. Med. Pet. 33: 81-87. 